\title{
DERMATOFITOSIS GENERALISATA PADA PASIEN LIMFOMA NON HODGKIN
}

\author{
Meidina K. Wardani, Johan Kartayana \\ Departemen Ilmu Kesehatan Kulit dan Kelamin \\ FK Universitas Sumatera Utara/RSUP Haji Adam Malik, Medan
}

\begin{abstract}
ABSTRAK
Pada beberapa keadaan, infeksi dermatofita dapat menyebabkan suatu keadaan infeksi yang luas, khususnya pada pasien imunokompromais, misalnya pada kasus keganasan dan HIV.

Seorang perempuan berusia 50 tahun dengan diagnosis Limfoma Non Hodgkin dikonsulkan dari poliklinik Penyakit Dalam dengan lesi berupa plak eritematosa, multipel, berbentuk anular, polisiklik dengan tepi aktif (central healing) pada regio kapitis, fasialis, colli, torakalis, abdominalis, braki dekstra, antebrachii dextra et sinistra, manus dekstra, inguinal, gluteal, dan ekstremitas inferior yang disertai dengan rasa gatal. Pada pasien kemudian dilakukan pemeriksaan KOH 10\% didapatkan gambaran struktur jamur berupa hifa dan pemeriksaan biakan ditemukan gambaran Trichophyton rubrum. Pasien diberikan terapi berupa itrakonazol oral sebanyak $2 \times 100 \mathrm{mg}$ yang diberikan selama 2 minggu.

Pada kasus ini infeksi dermatofita luas terjadi akibat keadaan imunokompromais yang disebabkan oleh Limfoma Non Hodgkin yang diderita oleh pasien maupun akibat kemoterapi. Terapi pilihan pada kasus ini adalah itrakonazol oral yang memberikan hasil sangat baik setelah 2 minggu.
\end{abstract}

Kata kunci: dermatofitosis, imunokompromais, Limfoma Non Hodgkin.

\section{GENERALIZED DERMATOPHYTOSIS INFECTION IN NON HODGKIN LYMPHOMA PATIENT}

\section{Korespondensi:}

Jl. Bunga Lau 17, Medan

Telp\&fax: 061-8365915

Email: meidinawardani01@gmail.com

\begin{abstract}
In several conditions dermatophyte infection can lead to a state of widespread infection, particularly in immunocompromised patients, such a as in cases of malignancy and Human Immunodeficiency Virus.

A woman aged 50 years with a diagnosis of Non Hodgkin Lymphoma with complaints plaque erythematous, multiple, annular and polycyclic shaped with active edge (central healing) accompanied by itching in the region capitis, facial, colli, thoracic, abdominal, brachii dextra, antebrachii dextra et sinistra, manus dextra, inguinal, gluteal and lower extremities. Patients then examined with $\mathrm{KOH} 10 \%$ is obtained in the form of fungal hyphae overview of the structure and the culture examination found Tricophyton rubrum. Patients were given oral itraconazole therapy $2 \times 100 \mathrm{mg}$ over 2 weeks.

In this case dermatophyte infections caused by a broad immunokompromaise, circumstances caused by Non Hodgkin Lymphoma that affect patient and treatment(chemotherapy). Treatment of choice in this case is oral itraconazole, where after therapy for 2 weeks obtained excellent results.
\end{abstract}

Keywords: dermatophytosis, imunocompromais, Non Hodgkin Lymphoma. 


\section{PENDAHULUAN}

Istilah dermatofita berasal dari bahasa Yunani yang berarti "kulit tanaman", dermatofita termasuk ke dalam famili arthrodermataceae, memiliki \pm 40 spesies dan dibagi menjadi tiga genus yaitu: Epidermophyton, Microsporum dan Trichophyton. Berdasarkan habitat alamiah dermatofita diklasifikasikan menjadi antropofilik, zoofilik dan geofilik. Kemampuan dermatofita untuk melekat dan menyerang jaringan keratin (kulit, rambut, dan kuku) dari manusia serta hewan, kemudian dikenal sebagai dermatofitosis. ${ }^{1,2}$

Selama lebih dari dua dekade terakhir infeksi dermatofita telah menjadi ancaman utama pada pasien kondisi imunokompromais, diperkirakan infeksi dermatofita menyerang $20-25 \%$ populasi di seluruh dunia. Usia, jenis kelamin, ras, migrasi manusia, status ekonomi yang rendah, higienitas, dan kontak dengan hewan peliharaan diperkirakan faktor yang memengaruhi penyebaran infeksi dermatofita. ${ }^{1,3,4}$
Infeksi pada umumnya disebabkan oleh dermatofita golongan antropofilik, zoofilik, maupun geofilik, misalnya Tricophyton rubrum, Tricophyton mentagrophytes, Tricophyton tonsurans, Tricophyton verrucosum, Microsporum canis, dan Microsporum audouinii. Trichophyton rubrum dianggap sebagai spesies dermatofita yang paling sering menyebabkan infeksi jamur pada kulit di seluruh dunia.,

Dermatofita diketahui memiliki enzim-enzim (keratinolytic protease, lipase dll) yang berperan sebagai faktor virulensi dan memungkinkan jamur untuk menginvasi kulit, rambut serta kuku. Proses patogenesis dari infeksi dermatofita melibatkan tiga langkah, yaitu perlekatan pada keratinosit, kemampuan penetrasi dan respons imun dari pejamu. Pada individu dengan keadaan immunokompromais, misalnya HIV, transplantasi organ, dan keganasan, infeksi dermatofita dapat berkembang dengan cepat dan meluas hingga ke seluruh tubuh. ${ }^{5-8}$

Tabel 1. Jenis-jenis dermatofita (dikutip sesuai aslinya dari kepustakaan no.1)

\begin{tabular}{|c|c|c|}
\hline Habitat & Dermatophyte & Host \\
\hline Anthropophilic & $\begin{array}{l}\text { Trichophyton rubrum } \\
\text { Trichophyton tonsurans } \\
\text { Trichophyton interdigitale (syn: } \\
\text { Trichophyton mentagrophytes var. } \\
\text { Interdigitale) } \\
\text { Trichophyton schoenleinii } \\
\text { T.rubrum (syn: Trichophyton megninii, } \\
\text { Trichophyton gourvilii) } \\
\text { Trichophyton soudanense } \\
\text { Trichophyton violaceum (syn: Trichophyton } \\
\text { yooundei) } \\
\text { Trichophyton concentricum } \\
\text { Microsporum audouinii } \\
\text { Microsporum ferrugineum } \\
\text { Epidermophyton floccosum }\end{array}$ & Humans \\
\hline \multirow[t]{3}{*}{ Zoophilic } & $\begin{array}{l}\text { T.mentagrophytes (syn: T.mentagrophytes } \\
\text { var.quinckeanum) } \\
\text { T.interdigitale (syn: T.mentagrophytes var. } \\
\text { mentagrophytes, T.mentagrophytes var. } \\
\text { granulosum) }\end{array}$ & $\begin{array}{l}\text { Rodents } \\
\text { Rodents }\end{array}$ \\
\hline & $\begin{array}{l}\text { Trichophyton erinacei } \\
\text { Trichophyton simii } \\
\text { Trchophyton verrucosum } \\
\text { Microsporum canis (syn: microsporum } \\
\text { distortum, Microsporum equinum) }\end{array}$ & $\begin{array}{l}\text { Hedgehogs } \\
\text { Primates } \\
\text { Cattle } \\
\text { Cats, dogs, horses }\end{array}$ \\
\hline & $\begin{array}{l}\text { Microsporum amazonicum } \\
\text { Microsporum gallinae } \\
\text { Microsporum nanum } \\
\text { Microsporum persicolor }\end{array}$ & $\begin{array}{l}\text { Rodents } \\
\text { Poultry } \\
\text { Pigs } \\
\text { Rodents }\end{array}$ \\
\hline Geophilic & $\begin{array}{l}\text { Microsporum gypseum } \\
\text { Microsporum cookie } \\
\text { Microsporum persicolor } \\
\text { Trichophyton vanbreuseghemii } \\
\text { Trichophyton eboreum } \\
\text { Trichophyton terrestre }\end{array}$ & Soil \\
\hline
\end{tabular}


Secara klinis lesi infeksi dermatofita biasanya berbentuk plak eritematosa (bulat, lonjong, atau polisiklik), berskuama dengan tepi lesi yang aktif (central healing), dan kadang pada tepi lesi ditemukan papul-papul eritematosa. Namun pada pasien imunokompromais, gambaran klinis yang timbul sering tidak jelas dan membingungkan, misalnya gambaran plak yang infitratif, nodus, dan ulserasi. ${ }^{5,6}$

Diagnosis infeksi dermatofita ditegakkan berdasarkan gambaran klinis dan didukung pemeriksaan penunjang, yaitu pemeriksaan kerokan kulit dengan larutan $\mathrm{KOH}$ $10 \%$ dan biakan. Pada pemeriksaan mikroskopis dapat dijumpai gambaran hifa yang bersepta dan bercabang, selain itu dapat juga dijumpai gambaran spora.,

Hingga saat ini belum ada konsensus pemberian terapi infeksi dermatofita yang luas dan invasif. Obat anti jamur misalnya terbinafin, itrakonazol, ketokonazol, amfoterisin B, flukonazol, dan griseofulvin telah digunakan baik sebagai terapi tunggal ataupun sebagai terapi kombinasi pada kasus-kasus infeksi dermatofita yang luas dan invasif. ${ }^{5}$

Limfoma Non-Hodgkin (LNH) merupakan tumor yang berasal dari jaringan limfoid, terutama dari kelenjar getah bening. LNH meliputi berbagai jenis kanker, $85-90 \%$ berasal dari limfosit $\mathrm{B}$ dan sisanya berasal dari limfosit $\mathrm{T}$ atau sel NK. Penyebab LNH hingga saat ini masih belum jelas, berbagai faktor risiko LNH telah diteliti, di antaranya infeksi virus Ebstein-Barr, faktor imunosupresi, infeksi HIV, infeksi virus Hepatitis C, transplantasi organ, human T-cell lymphotrophic virus 1 (HTVL-1). ${ }^{9,10}$

Insidens LNH lebih sering ditemukan di negara maju. Insiden LNH di Amerika sebesar 14 per 100.000 individu dan di Asia Selatan sebesar 3 per 100.000 individu. Gejala klinis LNH antara lain ditemukannya limfadenopati $(>1 \mathrm{~cm}$ dan menetap selama 6 minggu), hepato-splenomegali, rasa lelah, penurunan berat badan, demam, berkeringat pada malam hari. Terapi pilihan $\mathrm{LNH}$ adalah kemoterapi dan radioterapi. ${ }^{9-11}$

\section{KASUS}

Seorang perempuan berusia 60 tahun dikonsulkan dari Poliklinik THT ke Poliklinik Kulit dan Kelamin RSUP. H. Adam Malik, Medan, dengan keluhan bercak-bercak kemerahan disertai rasa gatal pada seluruh tubuh sejak 7 bulan sebelum datang ke rumah sakit. Awalnya bercak kemerahan timbul pada daerah perut, kemudian semakin melebar dan menyebar ke kepala, wajah, dada, lipatan payudara, lengan kanan dan kiri, tangan kanan, sela paha serta paha kanan dan kiri, disertai rasa gatal terutama bila pasien berkeringat. Pasien belum pernah berobat dan tidak ada anggota keluarga yang memiliki kelainan/keluhan yang sama. Pasien telah didiagnosis Limfoma Non Hodgkin oleh bagian THT sejak Juni 2013 dan mendapatkan kemoterapi yaitu siklofosfamid, doxorubicin dan vincristin.

Pada pemeriksaan fisis ditemukan keadaan umum pasien baik, kesadaran kompos mentis, status gizi baik, berat badan $50 \mathrm{~kg}$, tekanan darah 110/60 $\mathrm{mmHg}$, nadi $72 \mathrm{x} / \mathrm{menit}$, frekuensi pernapasan 16x/menit, suhu tubuh afebris. Pada pemeriksaan dermatologis, ditemukan plak hiperpigmentasi dengan tepi aktif, berbentuk polisiklik, permukaan lesi ditutupi skuama pada regio capitis, regio facialis sinistra dan colli anterior, kemudian didapatkan plak eritematosa dengan tepi aktif dan permukaan lesi yang ditutupi skuama halus pada regio temporalis dextra, brachii dextra et sinistra, antebrachii dextra, thoracalis, infra mammae, abdominalis, inguinalis, dan femoralis dextra et sinistra.
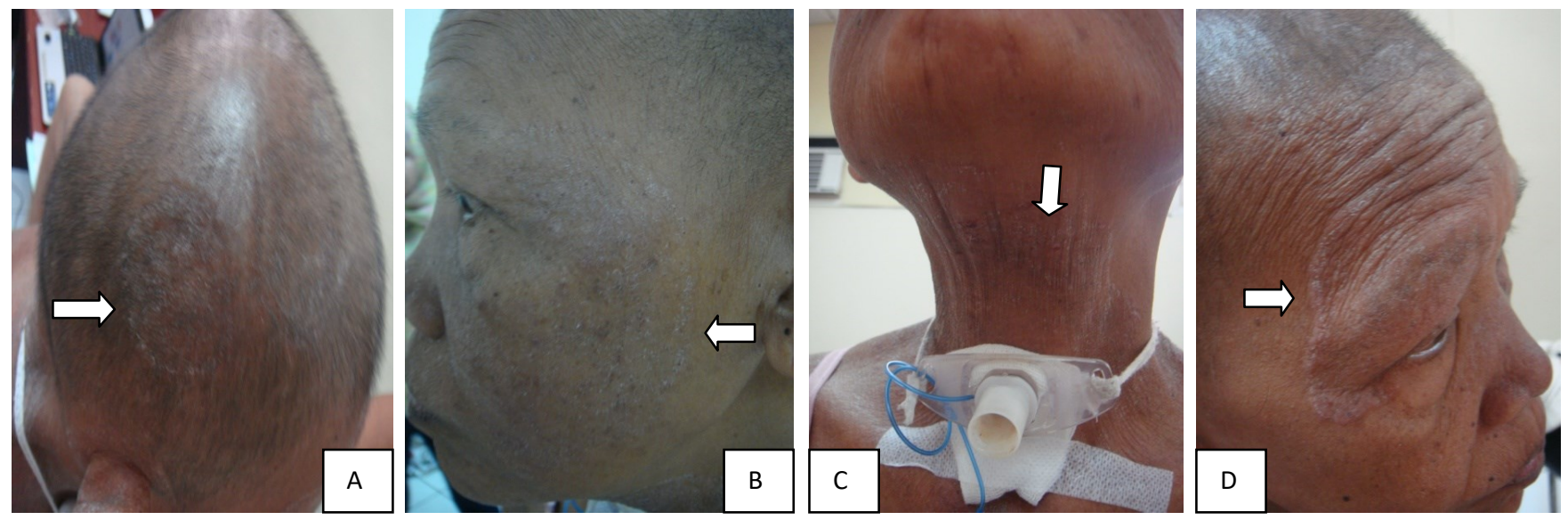

Gambar 1. Foto kunjungan pertama (A,B,C) plak hiperpigmentasi dengan tepi aktif disertai erosi dan skuama pada regio capitis, facialis sinistra dan colli anterior (D) plak eritematosa dengan tepi aktif dan skuama halus pada regio temporalis dextra. 

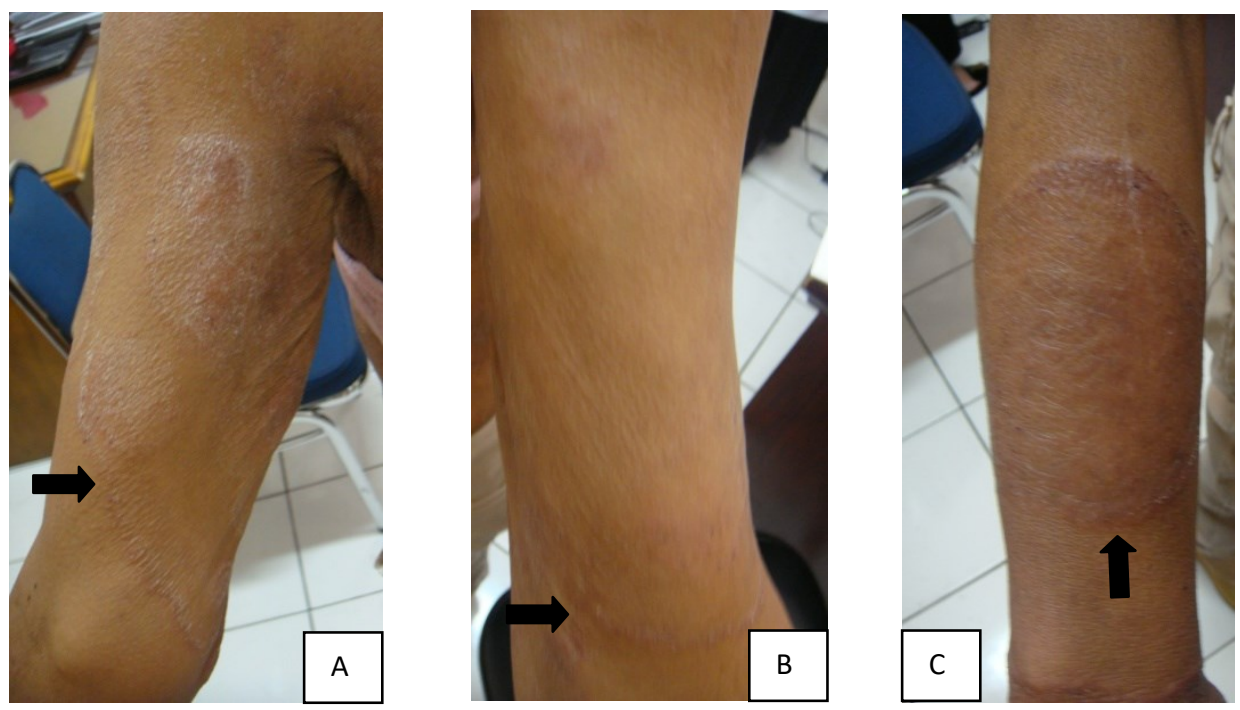

Gambar 2. Foto kunjungan pertama (A,B) Tampak lesi berupa plak eritematosa dengan tepi aktif, permukaan lesi ditutupi skuama pada regio brachii dextra et sinistra (C) tampak plak eritematosa berbentuk annular dengan tepi aktif pada regio antebrachii dextra.
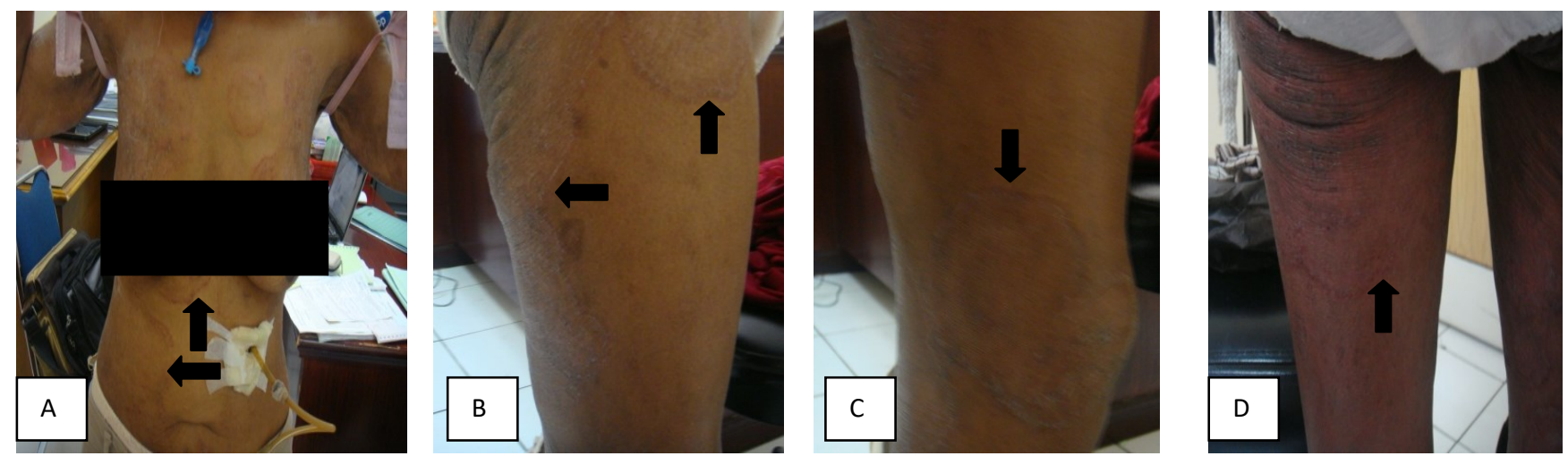

Gambar 3. Foto kunjungan pertama (A,B,C,D) Gambaran berupa plak eritematosa dengan tepi aktif, berbentuk polisiklik, permukaan lesi ditutupi skuama halus pada regio thoracalis, infra mammae, abdominalis, dan femoralis dextra et sinistra.

Diagnosis banding kasus ini ialah dermatofitosis generalisata, dermatitis seboroik, dan psoriasis vulgaris. Diagnosis sementara adalah dermatofitosis generalisata. Pada pasien dilakukan pemeriksaan kerokan kulit dengan $\mathrm{KOH} 10 \%$ dan kultur jamur. Spesimen diambil dari kerokan kulit di daerah kulit kepala, wajah, perut, dan kaki. Pada pasien juga dilakukan pemeriksaan laboratorium darah rutin, gula darah sewaktu, fungsi hati dan fungsi ginjal. Hasil pemeriksaan $\mathrm{KOH} \quad 10 \%$ ditemukan gambaran hifa, sehingga ditetapkan diagnosis kerja kasus ini adalah dermatofitosis generalisata. 

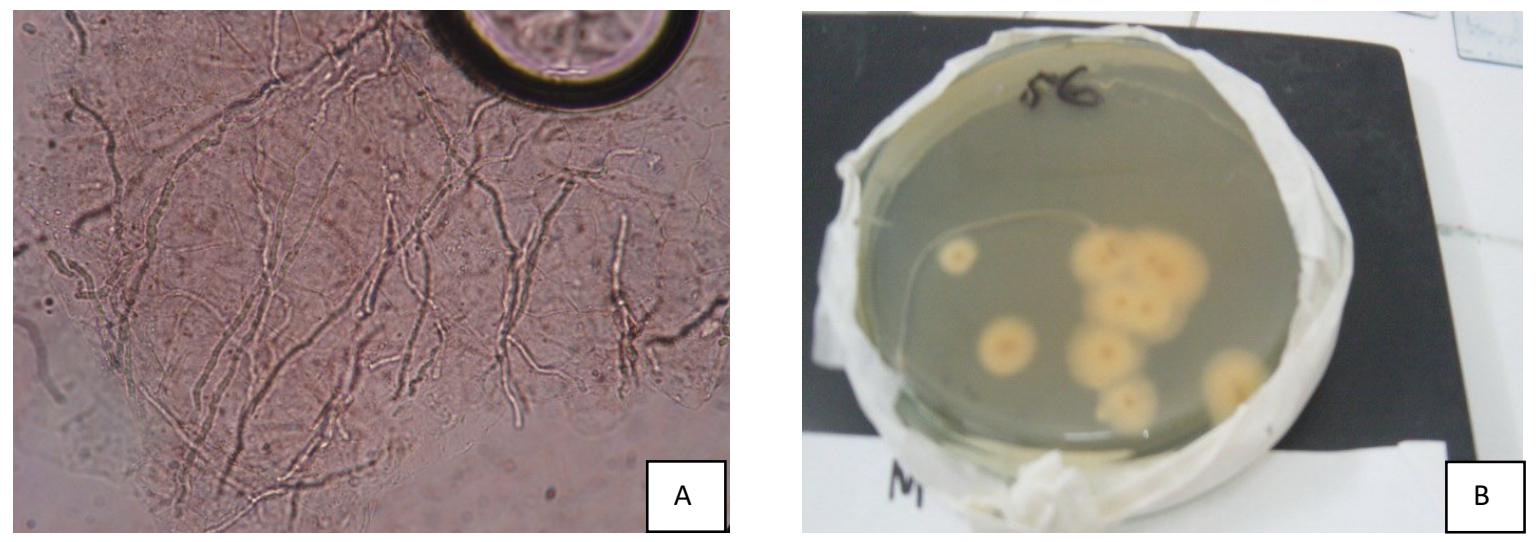

Gambar 4. Gambaran hifa pada kerokan kulit dengan $\mathrm{KOH} \mathrm{10 \% (A)} \mathrm{dan} \mathrm{hasil} \mathrm{kultur} \mathrm{jamur} \mathrm{didapatkan} \mathrm{pertumbuhan}$ jamur Trichophyton rubrum (B).

Penatalaksanaan pada pasien sementara menunggu hasil pemeriksaan laboratorium, yaitu sampo ketokonazol $2 \%$ (ketomed $^{\circledR}$ ) yang digunakan $2 \mathrm{x} /$ minggu dan tablet cetirizin 1 x $10 \mathrm{mg}$ per hari untuk mengurangi rasa gatal. Pasien direncanakan untuk diberikan kapsul itrakonazol 2 $\mathrm{x}$ 100mg selama 4 minggu dan juga diberikan edukasi mengenai penyakitnya, cara mencegah penularan dan selalu menjaga kebersihan diri.

Hasil pemeriksaan laboratorium pada tanggal 14 Maret 2014 menunjukkan hasil pemeriksaan darah rutin sebagai berikut: hemoglobin $12,5 \mathrm{~g} / \mathrm{dL}$, leukosit $5160 / \mathrm{mm}^{3}$, hematoksit $41,9 \%$, trombosit $402.000 / \mathrm{mm}^{3}$, hitung jenis (30/31/8/5/1), gula darah sewaktu $108 \mathrm{mg} / \mathrm{dL}$, ureum 27 $\mathrm{mg} / \mathrm{dL}$, kreatinin 0,8 mg/dL, SGOT $38 \mathrm{U} / \mathrm{L}$, SGPT 32 U/L. Pasien dikonsulkan ke Poliklinik Penyakit Dalam mengenai keadaan pasien dan rencana terapi yang akan diberikan, hasilnya tidak ditemukan kontraindikasi pemberian terapi pada pasien. Pasien diberikan terapi kapsul itrakonazol 2 x 100mg dan dianjurkan kontrol ulang 2 minggu kemudian

Pada kontrol ulang pertama 2 minggu kemudian, ditemukan lesi berupa makula hiperpigmentasi pada regio thoracalis, infra mammae, abdominalis, femoralis dextra et sinistra. Keluhan gatal sudah tidak dirasakan lagi oleh pasien. Hasil pemeriksaan kultur jamur ditemukan pertumbuhan Trichophyton rubrum. Terapi itrakonazol 2 x $100 \mathrm{mg}$ dan sampo ketokonazol $\left(\right.$ ketomed $^{\circledR}$ ) dilanjutkan, pasien disarankan kontrol kembali 2 minggu kemudian dan tetap diberikan edukasi untuk selalu menjaga kebersihan diri.
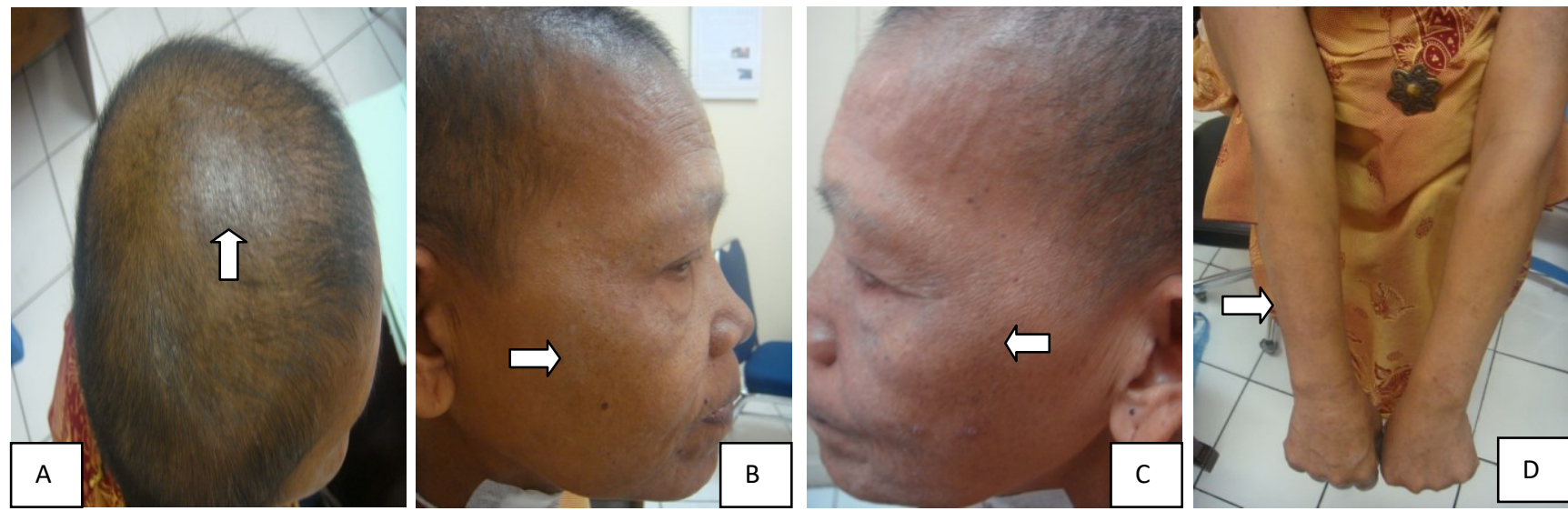

Gambar 5. Foto pasca 2 minggu pengobatan (A,B,C,D) Gambaran makula hiperpigmentasi pada regio kapitis, fasialis dan antebrachii dextra 

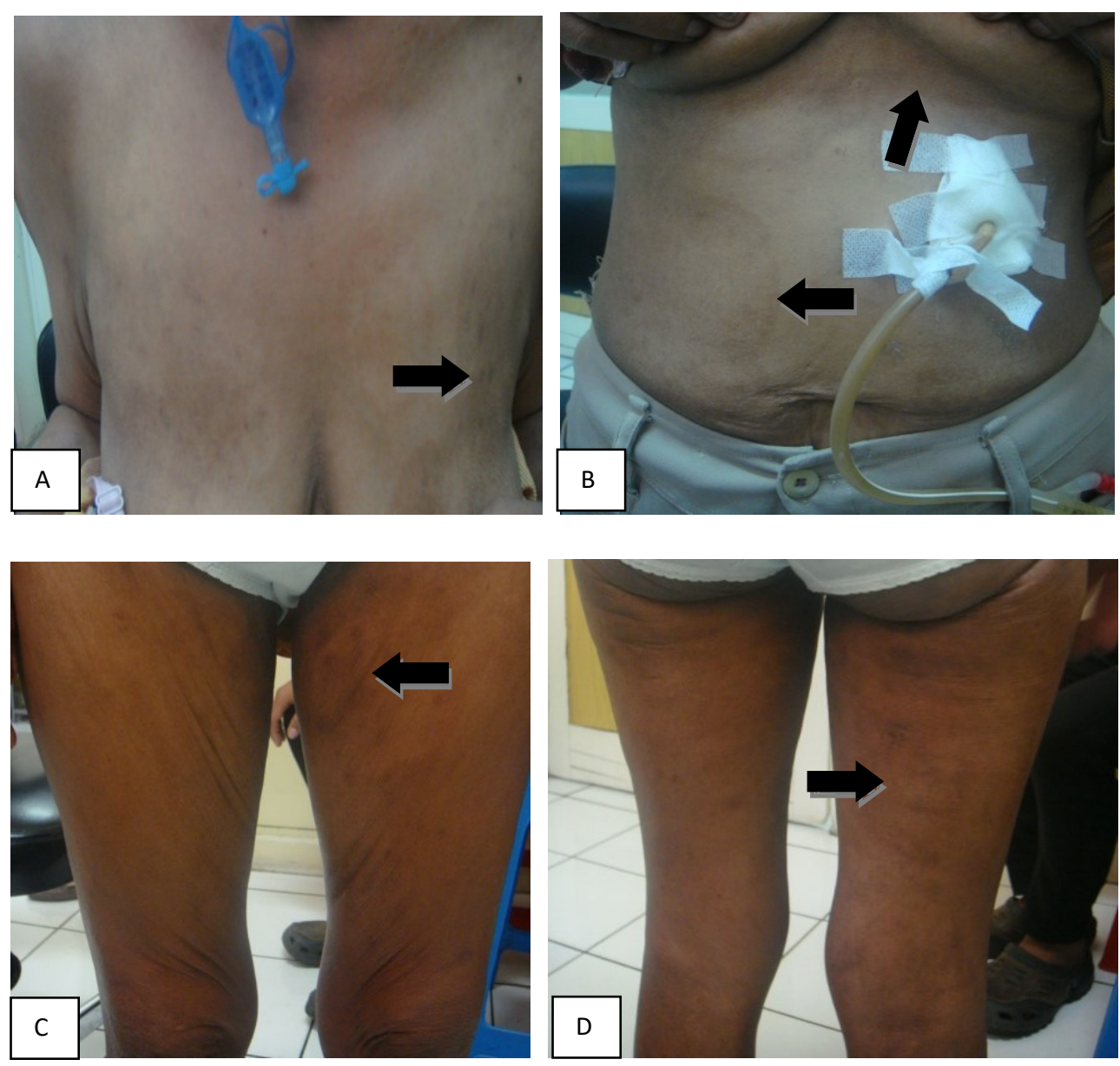

Gambar 6. Foto pasca 2 minggu pengobatan (A,B,C,D) plak eritema/hiperpigmentasi dengan tepi yang aktif tidak ditemukan lagi, didapatkan gambaran lesi berupa makula hiperpigmentasi regio thoracalis, infra mammae, abdominalis, dan femoralis anterior dan posterior dextra et sinistra

Pada kontrol ulang kedua, pada pemeriksaan dermatologis lesi makula hiperpigmentasi di regio thoracalis, infra mammae, abdominalis, femoralis dextra et sinistra sudah semakin menipis. Pada pasien kemudian dilakukan pemeriksaan ulang kerokan kulit $\mathrm{KOH} \mathrm{10 \% .}$ Hasil pada pemeriksaan $\mathrm{KOH} 10 \%$ tidak ditemukan adanya gambaran hifa maupun spora. Terapi itrakonazol oral dan sampo ketokonazol kemudian dihentikan.

Prognosis pada pasien ini quo ad vitam ad bonam, quo ad functionam ad bonam, dan quo ad sanationam ad bonam. 

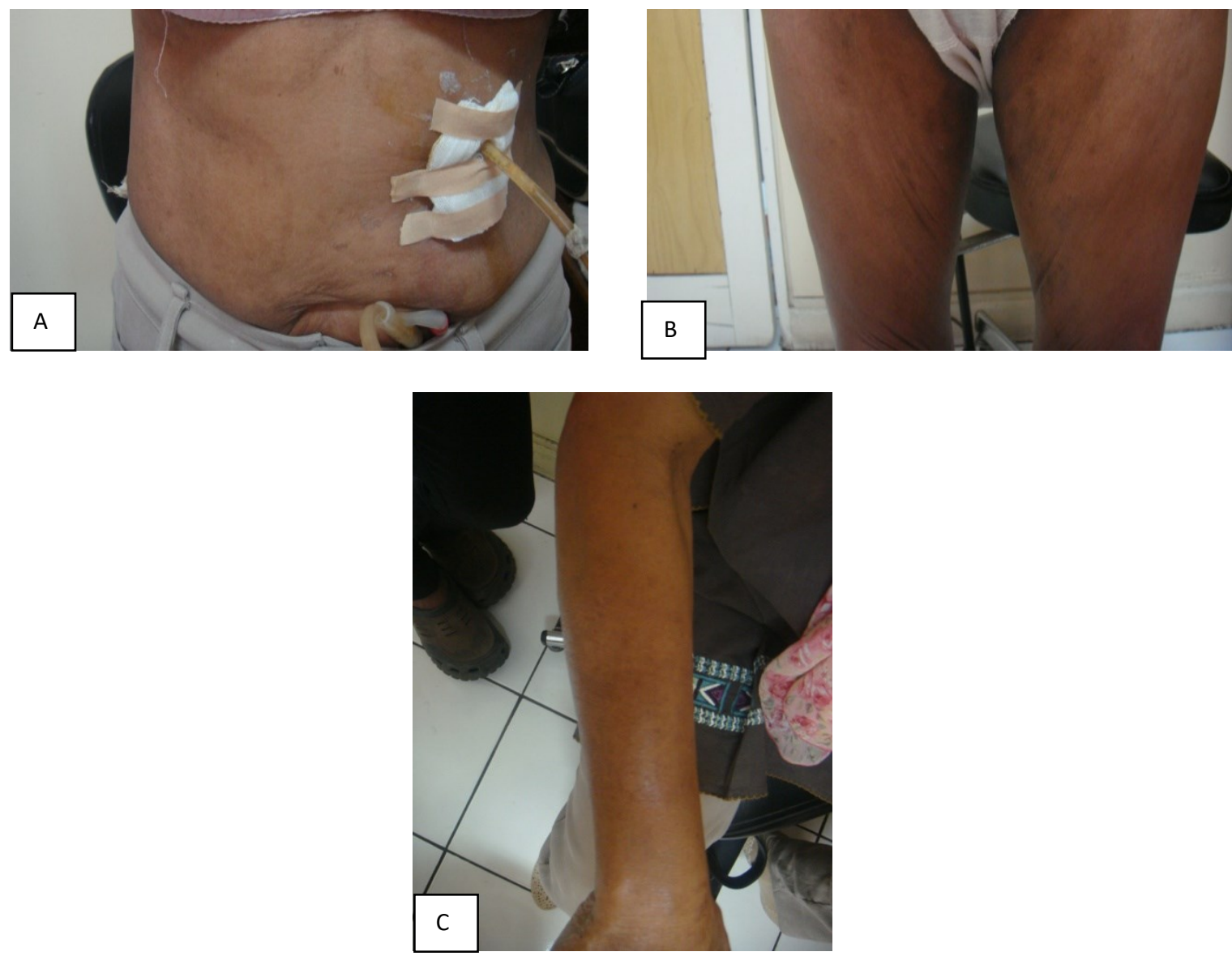

Gambar 7. Foto pasca pengobatan 4 minggu (A,B,C) Tampak makula hiperpigmentasi semakin menipis pada regio abdominalis, femoralis dextra et sinistra, antebrachii dextra

\section{DISKUSI}

Dilaporkan sebuah kasus dermatofitosis generalisata pada seorang perempuan berusia 60 tahun dengan Limfoma Non Hodgkin. Diagnosis pasien ditegakkan berdasarkan anamnesis, gambaran klinis, serta pemeriksaan penunjang berupa pemeriksaan $\mathrm{KOH} 10 \%$ dan kultur jamur.

Dari anamnesis didapatkan keluhan utama berupa bercak-bercak kemerahan pada seluruh tubuh disertai rasa gatal sejak \pm 6 bulan sebelum datang ke rumah sakit. Awalnya keluhan berupa bercak kemerahan pada daerah perut, yang semakin melebar dan menyebar ke daerah kepala, wajah, dada, lipatan payudara, sela paha, dan paha kanan dan kiri. Sesuai dengan kepustakaan infeksi dermatofita biasanya bersifat lokal, namun pada keadaan tertentu infeksi yang terjadi dapat bersifat luas, terutama pada pasien dengan keadaan imunosupresi. Hal ini karena faktor imun pejamu turut berperan pada sistem pertahanan tubuh terhadap infeksi jamur. Pada pasien Limfoma Non Hodgkin infeksi dermatofita luas dapat disebabkan oleh 2 hal yaitu akibat penyakit yang mendasarinya serta efek kemoterapi. Pasien Limfoma Non Hodgkin, mengalami gangguan atau perubahan sistem imun yang diperantarai oleh sel limfosit $\mathrm{T}$, dan sistem imunitas selular yang diperantarai oleh limfosit $\mathrm{T}$ merupakan faktor kunci dalam mekanisme pertahanan terhadap infeksi dermatofita, misalnya sel $\mathrm{T}$ Helper 1 yang berfungsi menghasilkan sitokin-sitokin seperti IFN $\gamma$, IL-2, TNF $\beta$, serta mengaktivasi sel-sel fagosit. Selain itu kemoterapi pada pasien Limfoma Non Hodgkin dapat menyebabkan deplesi limfosit dan neutropenia, sehingga turut berperan dalam memperberat infeksi dermatofita yang terjadi. ${ }^{4,6,}$

Pada pemeriksaan dermatologis, didapatkan lesi plak eritematosa dan hiperpigmentasi generalisata dengan tepi aktif berbentuk anular atau polisiklik dengan permukaan ditutupi skuama, gambaran klinis pasien ini sesuai dengan kepustakaan. Namun kadang pada pasien imunokompromais gambaran klinis dapat tidak khas. ${ }^{2,5,6}$

Pada pemeriksaan $\mathrm{KOH} 10 \%$ ditemukan berupa hifa bersepta yang bercabang dan pada kultur ditemukan pertumbuhan jamur dengan spesies Trichopyhton rubrum. 
Sesuai dengan kepustakaan, gambaran klinis infeksi dermatofita dikonfirmasi dengan pemeriksaan penunjang berupa pemeriksaan $\mathrm{KOH} 10 \%$ yang bertujuan untuk melihat adanya elemen jamur berupa hifa atau spora, dan pemeriksaan kultur untuk mengetahui spesies jamur penyebab. Walaupun sangat jarang, infeksi Trichophyton rubrum pada pasien imunokompromais dapat bersifat agresif dan luas, akan tetapi jarang melibatkan organ dalam. ${ }^{1,5,6}$

Diagnosis banding pada pasien adalah dermatofitosis generalisata, psoriasis vulgaris dan dermatitis seboroik. Diagnosis psoriasis vulgaris dapat disingkirkan karena pada psoriasis lesi biasanya berbentuk plak berbatas tegas yang ditutupi oleh skuama tebal pada permukaannya. Selain itu biasanya ditemukan auspitz sign (bintik-bintik perdarahan) ketika skuama dilepaskan. Kemudian diagnosis dermatitis seboroik dapat disingkirkan karena pada dermatitis seboroik lesi biasanya disertai skuama kekuningan dan berminyak. Selain itu diagnosis banding psoriasis dan dermatitis seboroik dapat disingkirkan dengan dijumpainya hifa pada pemeriksaan kerokan $\mathrm{KOH} 10 \%$ dan ditemukannya Trichophyton rubrum pada pemeriksaan kultur. ${ }^{1,6}$

Penatalaksanaan yang diberikan pada pasien ini adalah kapsul itrakonazol dengan dosis 2 x $100 \mathrm{mg} / \mathrm{hari}$ dan sampo ketokonazol 2\% $\left(\right.$ ketomed $\left.^{\circledR}\right)$ digunakan $2 \mathrm{x} / \mathrm{ming}$ gu, yang diberikan selama 4 minggu. Sesuai dengan kepustakaan, pilihan terapi kasus infeksi dermatofita yang mengenai kulit kepala atau rambut adalah itrakonazol oral, dosis sebesar $5 \mathrm{mg} / \mathrm{kgbb} /$ hari yang diberikan selama 2-4 minggu dikombinasikan dengan penggunaan sampo selenium sulfide $1 \%$ atau $2.5 \%$, ketokonazol $2 \%$ atau zinc pyrithione 1-2\%. Pada kasus infeksi dermatofita yang kronik dan luas diberikan itrakonazol 200mg yang diberikan selama 4-6 minggu. 1,2,12

Itrakonazol sangat efektif dalam mengobati hampir semua jenis infeksi dermatofita, bekerja dengan cara menghambat biosintesis ergosterol (inhibisi sitokrom p450) pada membran sel jamur. Selain itu itrakonazol tidak memiliki risiko hepatotoksik, bila dibandingkan dengan ketokonazol. Pemberian terapi anti jamur oral diindikasikan pada kasus infeksi dermatofita luas atau pada infeksi yang mengenai rambut atau kuku. Sampo ketokonazol 2\% diberikan sebagai terapi adjuvan, dimana pada kasus infeksi dermatofita yang mengenai rambut direkomendasikan untuk memberikan terapi kombinasi. 1,6,13,14

Prognosis pada pasien ini cukup baik. Setelah pemberian itrakonazol oral dosis $2 \times 100 \mathrm{mg}$ selama 4 minggu yang dikombinasikan dengan sampo ketokonazol $2 \%$, memberikan hasil perbaikan yang cukup signifikan pada pasien. Pada pemeriksaan $\mathrm{KOH} 10 \%$ terakhir tidak dijumpai lagi gambaran hifa maupun spora. Sesuai dengan kepustakaan pemberian terapi yang adekuat dan sesuai dengan dosis yang direkomendasikan memberikan hasil yang baik, walaupun kadang pada pasien imunokompromais dapat terjadi infeksi dermatofita yang berulang. ${ }^{6,7,13}$

\section{DAFTAR PUSTAKA}

1. Schieke SM, Garg A. Superficial fungal infection. Dalam: Wolff K, Goldsmith LA, Katz Si, Gilcrest BA, Paller AS, Leffel DJ, penyunting. Fitzpatrick's dermatology in general medicine. Edisi ke-8. New York: McGraw-Hill; 2012.h.3646-73

2. Richardson MD, Warnock DW. Dermatophytosis. Dalam: Richardson MD, Warnock DW, penyunting. Fungal Infection: Diagnosis and Management. Edisi ke3. Massachusetts: Blackwell Publishing; 2003.h.80-107

3. Havlickova B, Czaika VA, Friedrich M. Epidemiological trends in skin mycoses worldwide. Mycoses. 2008;51:2-15

4. Shoham S, Levitz SM. The immune response to fungal infections. Br J Haematol. 2005;129:569-82

5. Wu LC, Sun PL, Chang YT. Extensive deep dermatophytosis cause by Trichophyton rubrum in a patient with liver cirrhosis and chronic renal failure. Mycopathol. 2013;176:457-62

6. Hay RJ, Ashbee HR. Mycology. Dalam: Burns T, Breathnach S, Cox N, Griffiths C, penyunting. Rook's textbook of dermatology. Edisi ke-8. New Jersey: Wiley-BlackWell; 2010.h.1657-1750

7. Wanke B, Lazera MD, Nucci M. Fungal infections in the immunocompromised host. Mem Inst Oswaldo Cruz. 2000; $1: 153-8$

8. Marconi VC, Kradin R, Marty FM, Hospenthal DR, Kotton CN. Disseminated dermatophytosis in a patient with hereditary hemochromatosis and hepatic cirrhosis: case report and review of the literature. Med Mycol.2010;48:518-27

9. Shankland KR, Armitage JO, Hancock BW. NonHodgkin lymphoma. Lancet. 2012;380:848-57

10. Smedby KE. Epidemiology and etiology of nonHodgkin lymphoma - a review. Acta Oncol. 2006;45: 258-71

11. Evans LS, Hancock BW. Non-Hodgkin lymphoma. Lancet. 2003;362: 139-46

12. Ellis D, Watson A. Systemic antifungal agents for cutaneous fungal infections. Aust Prescr. 1996;19: 72-5

13. Aly R, Berger T. Common superficial fungal infections in patients with AIDS. Clin Infec Dis. 1996;22: 128-32

14. Gupta AK, Cooper EA. Update in antifungal therapy of dermatophytosis. Mycopathol. 2008;166: 353-67 